\title{
Role of the $\beta$-Catenin/REG I $\alpha$ Axis in the Proliferation of Sessile Serrated Adenoma/Polyps Associated with Fusobacterium nucleatum
}

\author{
Heihachiro Nishimura ${ }^{1}$, Hirokazu Fukui ${ }^{1, *}$, Xuan Wang ${ }^{1}$, Nobuhiko Ebisutani ${ }^{1}{ }^{(D)}$, Takashi Nakanishi ${ }^{1}$, \\ Toshihiko Tomita $^{1}{ }^{(D)}$, Tadayuki Oshima ${ }^{1} \mathbb{D}$, Seiichi Hirota $^{2}$ and Hiroto Miwa ${ }^{1}$
}

1 Division of Gastroenterology and Hepatology, Department of Internal Medicine, Hyogo College of Medicine 1-1, Mukogawa, Nishinomiya 663-8501, Japan;

he-nishimura@hyo-med.ac.jp (H.N.); xwang31@tmu.edu.cn (X.W.); no-ebisutani@hyo-med.ac.jp (N.E.); ta-nakanishi@hyo-med.ac.jp (T.N.); tomita@hyo-med.ac.jp (T.T.); t-oshima@hyo-med.ac.jp (T.O.); miwahgi@hyo-med.ac.jp (H.M.)

2 Department of Surgical Pathology, Hyogo College of Medicine 1-1, Mukogawa, Nishinomiya 663-8501, Japan; hiros@hyo-med.ac.jp

* Correspondence: hfukui@hyo-med.ac.jp; Tel.: +81-798-456-662

\section{check for} updates

Citation: Nishimura, H.; Fukui, H. Wang, X.; Ebisutani, N.; Nakanishi, T.; Tomita, T.; Oshima, T.; Hirota, S.; Miwa, H. Role of the $\beta$-Catenin/REG I $\alpha$ Axis in the Proliferation of Sessile Serrated Adenoma/Polyps Associated with Fusobacterium nucleatum. Pathogens 2021, 10, 434 https://doi.org/10.3390/ pathogens 10040434

Academic Editor: Jorge Luis Espinoza

Received: 3 February 2021

Accepted: 2 April 2021

Published: 6 April 202

Publisher's Note: MDPI stays neutra with regard to jurisdictional claims in published maps and institutional affiliations.

Copyright: (c) 2021 by the authors. Licensee MDPI, Basel, Switzerland. This article is an open access article distributed under the terms and conditions of the Creative Commons Attribution (CC BY) license (https:// creativecommons.org/licenses/by/ $4.0 /)$

\begin{abstract}
Although sessile serrated adenoma/polyps (SSA/Ps) may arise through a pathway different from the traditional adenoma-carcinoma sequence, details of SSA/P tumorigenesis still remain unclear. Fusobacterium nucleatum (Fn) is frequently detected in colorectal cancer (CRC) tissues and may play a pivotal role in colorectal carcinogenesis. Here, we investigated the relationship between $F n$ and the $\beta$-catenin/REG I $\alpha$ axis in SSA/Ps and their involvement in the proliferation of these lesions. $F n$ was detected in SSA/Ps by fluorescence in situ hybridization using a $F n$-targeted probe, and expression of $\beta$-catenin, REG I $\alpha$ and Ki67 was examined using immunohistochemistry. Sixteen of 30 SSA/P lesions (53.3\%) were positive for $F n$. Eighteen SSA/P lesions (60\%) showed $\beta$-catenin immunoreactivity in the tumor cell nuclei. A significant majority of $F n$-positive lesions showed nuclear expression of $\beta$-catenin (87.5\%) and higher REG I $\alpha$ scores and Ki67 labeling indices relative to $F n$-negative lesions. The SSA/P lesions expressing $\beta$-catenin in nuclei had significantly higher REG I $\alpha$ scores and Ki67 labeling indices than those expressing $\beta$-catenin on cytomembranes. The REG I $\alpha$ score was positively correlated with the Ki67 labeling index in SSA/P lesions. The treatment with Wnt agonist SKL2001 promoted nuclear $\beta$-catenin translocation and enhanced REG Ia expression in Caco2 cells. Fn may play a role in the proliferation of SSA/P lesions through promotion of $\beta$-catenin nuclear translocation and REG I $\alpha$ expression.
\end{abstract}

Keywords: Fusobacterium nucleatum; sessile serrated adenoma; polyp; $\beta$-catenin; REG; Ki67; proliferation

\section{Introduction}

Although it is widely accepted that colorectal cancers (CRCs) arise from adenomas [1], the pathway responsible has recently been shown to be far from simple [2]. Among colorectal adenomas, sessile serrated adenoma/polyps (SSA/Ps) are classified as a subgroup exhibiting a specific saw-toothed colonic crypt morphology and genetic alterations such as $B R A F$ mutation and microsatellite instability [3,4]. Furthermore, SSA/Ps lesions show highlabeling index for Ki67 expression [5], suggesting that those lesions have high ability in cell proliferation. These morphologic and genetic alterations are quite different from those in conventional adenomas, from which CRCs arise through accumulation of $A P C, K R A S$ and p53 mutations in multiple steps [1]. Thus, the molecular mechanism whereby CRCs arise and progress from adenomas is not fully clear. In addition to genetic alterations, the role of the gut microbiome in colorectal carcinogenesis has been highlighted; microbiome imbalance (dysbiosis) is closely associated with the development and progression of CRCs 
through promotion of chronic inflammatory conditions and production of carcinogenic metabolites [6]. Among various candidate pathogenic bacteria, Fusobacterium nucleatum (Fn) has been gathering the most attention, since numerous studies have reported that a higher abundance of $F n$ is associated with a more advanced stage, a higher risk of recurrence, and shorter survival in patients with CRC [7-9]. However, it is still debatable whether Fn directly plays a role in the pathogenesis of CRC patients although $F n$ may promote colorectal carcinogenesis by activating $\beta$-catenin signaling in vitro experiments $[10,11]$.

The regenerating gene (REG) was first isolated from rat regenerating pancreatic islets [12], and since then, many REG-related genes have been isolated, currently constituting a family with multiple members (types I-IV) $[13,14]$. We and others have reported that REG family proteins play some roles in not only inflammatory [15-18] but also neoplastic [19-21] diseases of the gastrointestinal (GI) tract. In fact, REG I $\alpha$ protein, as well as other REG family proteins [22-24], are suggested to exert a cell proliferative and/or anti-apoptotic effect in inflamed and neoplastic lesions in the GI tract [25-27]. In relation to the up-regulation of REG I $\alpha$ expression in GI neoplasia, we have previously clarified that STAT3-associated cytokines play a pivotal role in REG I $\alpha$ overexpression in gastric cancer cells [28]. However, the mechanism by which REG I $\alpha$ overexpression is regulated in neoplastic lesions remains unclear. On the other hand, it is well known that $\beta$-catenin signaling is one of the major pathways of carcinogenesis in colorectal tumors, including SSA/Ps $[29,30]$. In this regard, it is interesting to speculate that $\beta$-catenin mutation and aberrant $\beta$-catenin expression may be linked to REG I $\alpha$ overexpression in hepatocellular carcinoma, colorectal tumors, or salivary tumors [31,32]. In the present study, therefore, we focused on the relationship between $F n$ abundance and the $\beta$-catenin/REG I $\alpha$ axis and investigated its significance for the proliferative ability of SSA/P lesions.

\section{Results}

\subsection{Detection of Fusobacterium Nucleatum in SSA/P Lesions}

The FISH signal for Fn was detected not only on the luminal surface but also the lamina propria of SSA/P lesions (Figure 1). We evaluated the density of the signal population (magnification $\times 200$ ) in both SSA/P lesions and in the adjacent non-neoplastic regions. As the density in the non-neoplastic regions was $0.81 \pm 0.15$ (maximum 2.50), we considered any SSA/P lesion to be positive for $F n$ if the signal density was more than 3.0. Based on this definition, 16 of $30 \mathrm{SSA} / \mathrm{P}$ lesions (53.3\%) were positive for $\mathrm{Fn}$ in the samples examined. None of the determined parameters-age, gender, tumor location, or endoscopic morphology - showed a significant relationship to Fn positivity.
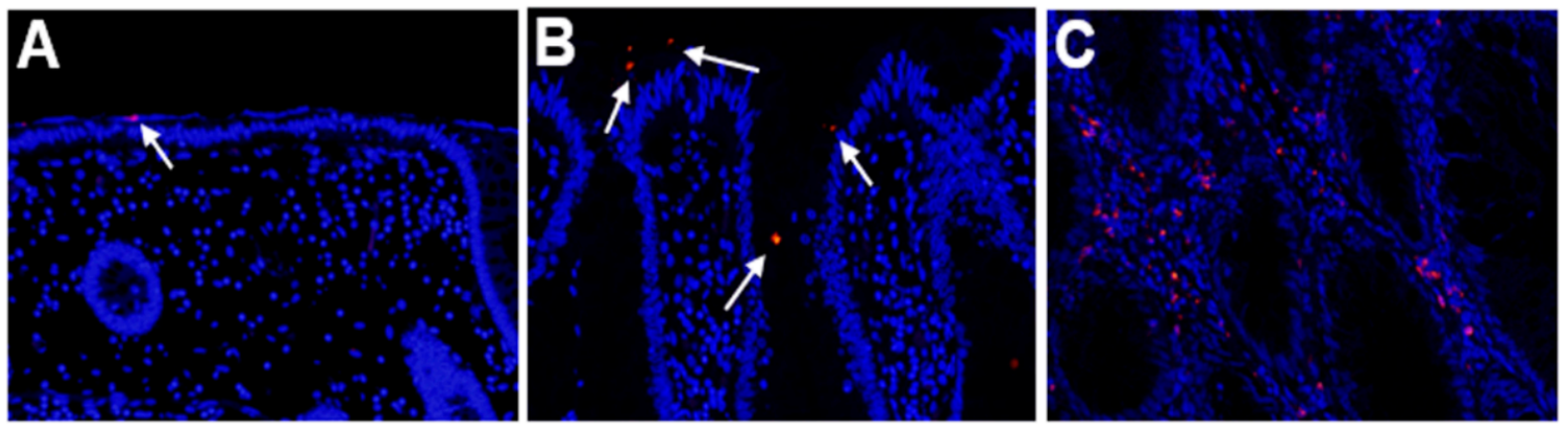

Figure 1. Detection of Fusobacterium nucleatum $(F n)$ by fluorescence in situ hybridization. (A) Non-neoplastic colonic mucosa adjacent to a sessile serrated adenoma/polyp (SSA/P) lesion. (B,C) SSA/P lesions. The signals (red dots) for Fn are evident at the surface (B) or lamina propria (C) of the SSA/P lesions but are hardly evident in the non-neoplastic mucosa. Signals are indicated by white arrows.

\subsection{Expression of REG I $\alpha$ and $\beta$-Catenin in SSA/P Lesions}

REG I $\alpha$ was expressed in a few epithelial cells in non-neoplastic crypts in the colonic mucosa (Figure 2A). In SSA/P lesions, REG I $\alpha$ was expressed mainly in goblet cells, and 
we scored its expression as described in materials and methods. All of the SSA/P lesions showed apparently higher scores for REG I $\alpha$ expression than their adjacent non-neoplastic areas (Figure 2A-D). The REG I $\alpha$ expression score was significantly higher in SSA/Ps on the right side of the colon $(1.71 \pm 0.11, p<0.05)$ than in those on the left side of the colon $(0.90 \pm 0.31)$. None of the remaining parameters had any significant relationship to the REG I $\alpha$ expression score.

Immunoreactivity for $\beta$-catenin was detected in the cytomembranes of non-neoplastic epithelial cells in the colonic mucosa (Figure 2E). In SSA/P lesions, $\beta$-catenin immunoreactivity was detected in not only cytomembranes (Figure $2 \mathrm{~F}$ ) but also the nuclei of serrated epithelial cells (Figure 2G). Twelve of the 30 SSA/P lesions (40\%) showed a cytomembranetype $\beta$-catenin staining pattern, whereas 18 of them $(60 \%)$ showed nuclear-type immunostaining. None of the clinicopathological parameters examined had a significant relationship to the $\beta$-catenin expression pattern.

Ki67 was sparsely expressed in the lower portion of non-neoplastic crypts in the colonic mucosa (Figure 2H). On the other hand, Ki67 immunoreactivity was apparently increased, mainly at the bottom of serrated glands (Figure 2I). None of the clinicopathological parameters examined showed a significant relationship to the Ki67 labeling index.
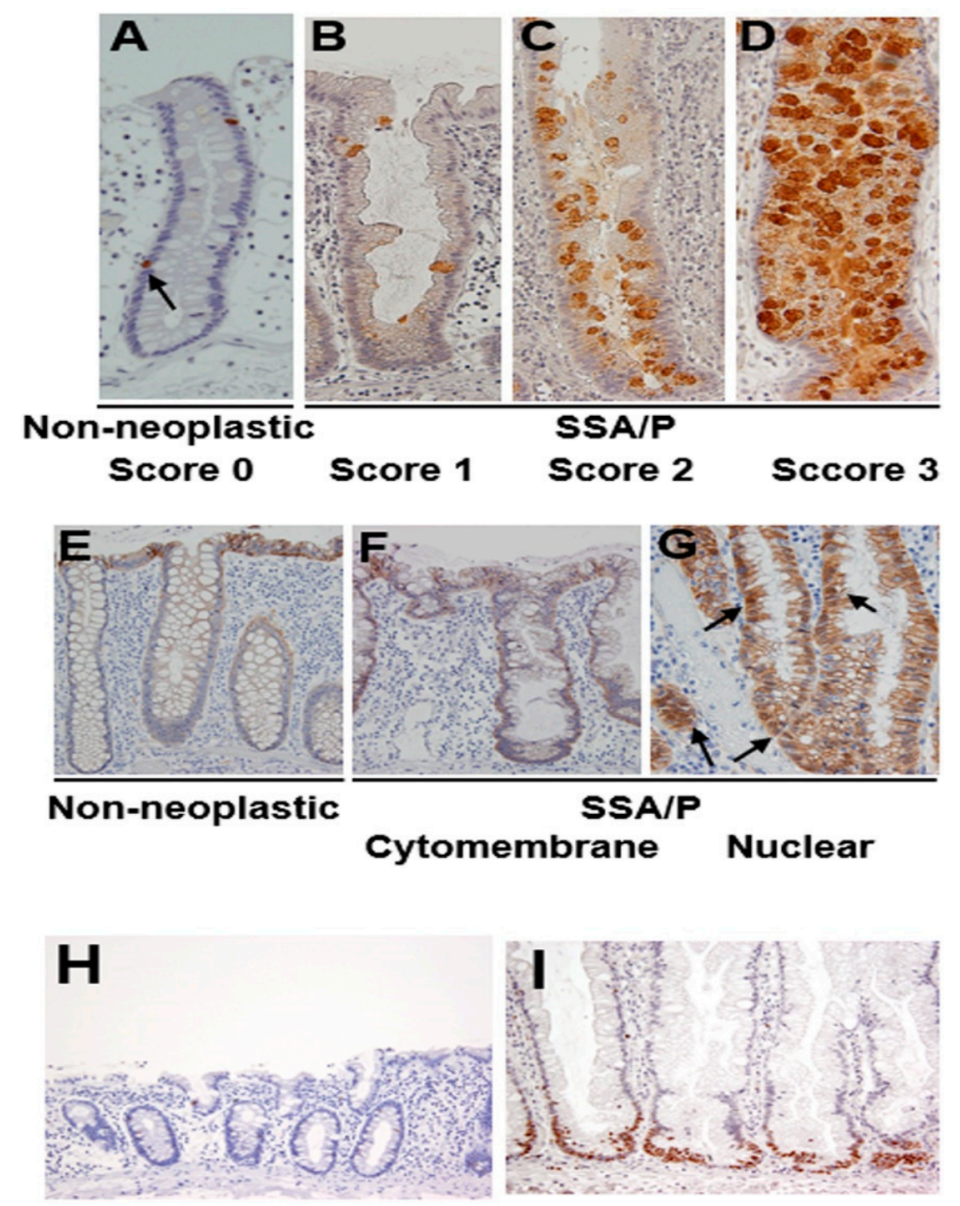

Figure 2. Expression of REG I $\alpha, \beta$-catenin and Ki67 in SSA/P and its adjacent non-neoplastic mucosa in the colon. (A-D) Grading of REG I $\alpha$ expression in SSA/P lesions and non-neoplastic colonic mucosa. (E-G) $\beta$-catenin expression pattern in SSA/P lesions and non-neoplastic colonic mucosa. Arrows indicate nuclear expression of $\beta$-catenin. (H,I) Expression of Ki67 in SSA/P lesions and non-neoplastic colonic mucosa. 
2.3. Relationships among REG I $\alpha / \beta$-Catenin Expression, Fusobacterium Nucleatum Abundance, and Proliferative Activity in SSA/P Lesions

We investigated the relationship between $F n$ positivity and REG I $\alpha / \beta$-catenin expression in SSA/P lesions (Table 1). The REG I $\alpha$ expression score was significantly higher in Fn-positive SSA/P lesions. Fn-positive SSA/P lesions showed a significant preponderance of nuclear-type $\beta$-catenin expression, whereas $F n$-negative SSA/P lesions tended to show cytomembrane-type expression. In terms of cell proliferative ability, the Ki67 labeling index was significantly higher in Fn-positive than in negative SSA/P lesions.

Table 1. Association between $F n$ presence and $\beta$-catenin, REG I $\alpha$, or Ki67 expression in SSA/P lesions.

\begin{tabular}{cccc}
\hline & \multicolumn{2}{c}{ Fusobacterium } & nucleatum \\
Pegative & & Positive & Value \\
\hline B-catenin expression & 10 & 2 & 0.001 \\
Cytomembrane type & 4 & 14 & \\
Nuclear type & $1.23 \pm 0.15$ & $1.85 \pm 0.14$ & $<0.01$ \\
REG I $\alpha$ expression score & $7.0 \pm 1.3$ & $16.8 \pm 2.3$ & $<0.01$ \\
Ki67 labeling index & & & \\
\hline
\end{tabular}

We then investigated the correlation between REG I $\alpha / \beta$-catenin expression and the Ki67 labeling index. As shown in Figure 3A, the REG I $\alpha$ expression score was significantly correlated with the Ki67 labeling index. In addition, SSA/P lesions with nuclear $\beta$-catenin expression showed a significantly higher Ki67 labeling index than lesions with cytomembrane expression (Figure 3B). These findings suggested that expression of REG I $\alpha$ and nuclear $\beta$-catenin was linked to the proliferative ability of SSA/P lesions. It was also evident that SSA/P lesions with nuclear $\beta$-catenin expression had a significantly higher REG I $\alpha$ score than lesions with cytomembrane expression (Figure 3C).
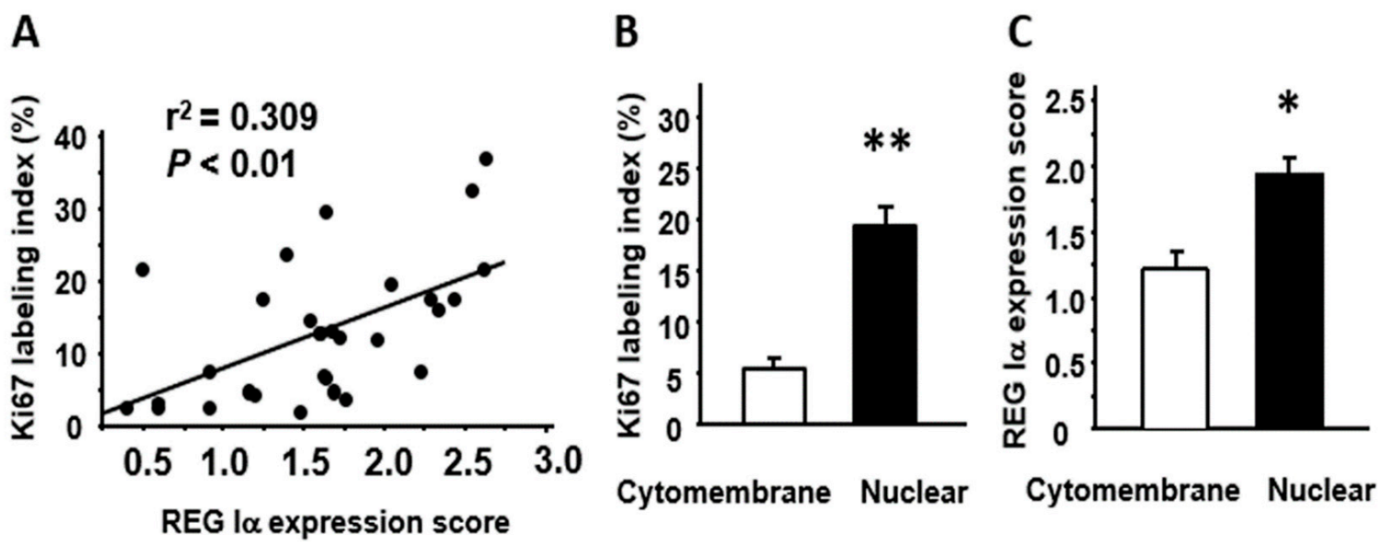

Figure 3. Relationships among REG $\mathrm{I} \alpha, \beta$-catenin, and Ki67 expression in SSA/P lesions. (A) Correlation between the REG I $\alpha$ expression score and the Ki67 labeling index in SSA/P lesions. (B) Comparison of Ki67 labeling index between SSA/P lesions with cytomembrane-type $\beta$-catenin expression and those with nuclear-type expression. (C) Comparison of REG I $\alpha$ expression score between SSA/P lesions with cytomembrane-type $\beta$-catenin expression and those with nuclear-type expression. Results are expressed as the mean $\pm \mathrm{SE}$. ${ }^{*} p<0.005,{ }^{* *} p<0.001$ vs. cytomembrane-type group.

\subsection{Relationship among Histology, Tumor Size, and REG I $\alpha / \beta$-catenin/Ki67 Expression in SSA/P Lesions}

Since $\beta$-catenin nuclear translocation may occur in SSA/P at the transition to dysplasia [29], we investigated the relationships among pathological features and REG I $\alpha / \beta$ catenin/Ki67 expression in SSA/P lesions. Subsequently, the SSA/Ps with dysplastic change significantly showed nuclear $\beta$-catenin expression and, moreover, had a significantly higher score for REG I $\alpha$ expression (Table 2). In addition, those SSA/Ps tended 
to show higher Ki67 labeling index compared with ones without. Regarding the size of $\mathrm{SSA} / \mathrm{P}$, we found no significant relations to $\beta$-catenin (cytomembrane vs. nuclear: $23.4 \pm$ 2.5 vs. $19.5 \pm 1.8 \mathrm{~mm})$, REG I $\alpha\left(\mathrm{r}^{2}=0.02, p=0.45\right)$, or $\mathrm{Ki} 67\left(\mathrm{r}^{2}=0.03, p=0.88\right)$ expression in this study.

Table 2. Association between dysplastic change and $\beta$-catenin, REG I $\alpha$ or Ki67 expression in SSA/P lesions.

\begin{tabular}{cccc}
\hline & \multicolumn{2}{c}{ Dysplastic Change } & p Value \\
\hline$\beta$-catenin expression & $(-)$ & $(+)$ & 0.025 \\
Cytomembrane type & 9 & 3 & \\
Nuclear type & 6 & 12 & \\
REG I $\boldsymbol{\alpha}$ expression score & $1.35 \pm 0.16$ & $1.85 \pm 0.15$ & 0.019 \\
Ki67 labeling index & $10.7 \pm 2.5$ & $15.1 \pm 2.3$ & 0.130 \\
\hline
\end{tabular}

\subsection{Effect of Wnt Signaling on Nuclear $\beta$-Catenin Translocation and REG I $\alpha$ Expression in Caco2 Cells}

When Caco2 cells were stimulated with Wnt agonist SKL2001, the immunoreactivity for $\beta$-catenin was detected not only at the cytomembrane but also in the cytoplasm and the nuclei in the cells, suggesting that nuclear $\beta$-catenin translocation was promoted in those cells (Figure 4A). Furthermore, the expression of REG I $\alpha$ was significantly enhanced in Caco2 cells by the treatment with Wnt agonist SKL2001 (Figure 4B).
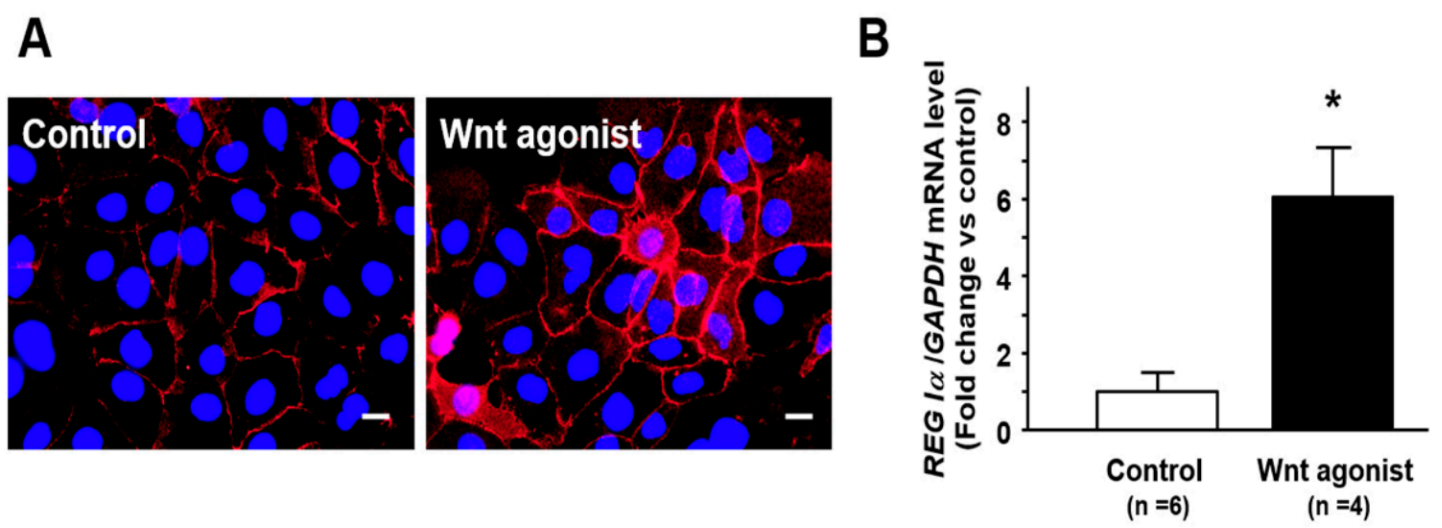

Figure 4. Effect of Wnt agonist SKL2001 on nuclear $\beta$-catenin translocation and REG I $\alpha$ expression in Caco2 cells. (A) Representative photograph showing nuclear $\beta$-catenin (red) translocation in Caco2 cells treated with Wnt agonist SKL2001. Caco2 cells $\left(5 \times 10^{4}\right)$ were cultured in 12-well plates for $24 \mathrm{~h}$ and then treated with Wnt agonist SKL2001 (40 mM) for $24 \mathrm{~h}$. After stimulation, the cells were fixed with methanol for $10 \mathrm{~min}$ at room temperature, incubated with primary anti- $\beta$-catenin antibody for $1 \mathrm{~h}$, followed by TRITC-labeled secondary anti-rabbit antibodies for $1 \mathrm{~h}$, nuclear counterstained using Antifade Mountant with DAPI (blue) and observed under Olympus BX53 microscope. Bar $=20 \mathrm{~mm}$. (B) Change in REG I $\alpha$ expression in in Caco2 cells treated with Wnt agonist SKL2001. Results are expressed as the mean \pm SE. ${ }^{*} p<0.05$ vs. control group.

\section{Discussion}

The mechanism of CRC development has been largely studied by focusing on genetic alterations, but recent investigators have begun to recognize the role of the gut microbiome in this respect [6], similarly to the role of Helicobacter pylori in gastric cancer development [33]. So far, comprehensive analyses of the gut microbiome have identified several candidate bacteria that may play a role in the development of CRC, and among them, Fn has received special attention [7-9]. In the present study, we were able to detect the presence of $F n$ in approximately half of the SSA/P lesions we examined, in agreement with a previous report [34]. One limitation in this study was that we were unable to address the mechanism whereby $F n$ affects the carcinogenesis of CRC. However, since 
SSA/P lesions are known to show high proliferative ability [5], we investigated the relationship between $F n$ positivity and proliferative ability in SSA/P lesions and subsequently clarified that $F n$-positive lesions had higher proliferative ability than Fn-negative lesions. In addition to proliferative ability, $F n$ infection appears to accelerate inflammation and DNA damage in colonic epithelial cells, and those accelerations may be regulated by a specific DNA glycosylase [35]. These findings suggest that not only cell proliferation, but also inflammation-associated DNA damage may be a key to understand the effect of $F n$ infection on the progression of malignant potential in SSA/P lesions.

Of note, $\beta$-catenin nuclear translocation is likely to occur in SSA/P lesions at the transition to dysplasia $[29,36]$, being compatible with our obtained data in this study. This finding may suggest that nuclear $\beta$-catenin expression may be a marker of high risk of malignant progression in SSA/P lesions. Interestingly, recent studies have clarified that $F n$ is likely to promote CRC growth through the formation of a FadA-E-cadherin-annexin A1- $\beta$-catenin complex to activate the nuclear translocation of $\beta$-catenin $[10,11]$. Furthermore, another study has demonstrated that $F n$ may promote the nuclear translocation of $\beta$-catenin via a TLR4/P-PAK1 cascade in colorectal cancers [37]. In this respect, it was noteworthy in this study that Fn-positive SSA/P lesions showed significant nuclear immunoreactivity for $\beta$-catenin. Moreover, we found that SSA/P lesions with a nuclear $\beta$-catenin immunostaining pattern had a significantly higher Ki67 labeling index than lesions with cytomembrane immunostaining, indicating that SSA/P lesions with nuclear $\beta$-catenin expression had higher proliferative ability. As we demonstrated in this study, $\beta$-catenin is normally localized on the cytomembranes of non-neoplastic epithelial cells in the colonic mucosa. However, nuclear translocation of $\beta$-catenin is often observed in various tumors, and such translocated $\beta$-catenin acts as a transcriptional factor to regulate the expression of its target genes [38,39]. Although we cannot explain exactly why SSA/P lesions with a nuclear $\beta$-catenin immunostaining pattern have higher proliferative ability, we speculate that $F n$-associated $\beta$-catenin nuclear translocation may play at least some role in the proliferation of SSA/P lesions. Moreover, it has been known that APC mutations and APC-related abnormalities are less common in SSA/Ps $[40,41]$. Conversely, this suggests that $A P C$-unrelated $\beta$-catenin activation, such as $F n$-associated ones, may play a pivotal role in progression of SSA/P lesions.

Vigorous mucin production is one characteristic of SSA/P lesions [41,42]. Of note, REG I $\alpha$ protein is overexpressed in precancerous metaplasia and adenoma that actively express various mucin phenotypes $[19,26,43]$. Moreover, REG I $\alpha$ protein functions as a growth and/or anti-apoptotic factor in gastrointestinal tumors $[26,27,43]$, which prompted us to investigate REG I $\alpha$ expression in SSA/P lesions. In non-neoplastic crypts, REG I $\alpha$ is expressed in a few endocrine cells with an ovoid or pyramidal morphology, whereas all of the present SSA/P lesions apparently overexpressed REG I $\alpha$ protein. Interestingly, the REG I $\alpha$ expression score was positively correlated with the Ki67 labeling index in SSA/P lesions. This suggests that REG I $\alpha$ expression is associated with the proliferative ability of these lesions, which would be reasonable in view of the known cell growth effect of REG I $\alpha$ protein. However, one might be concerned whether REG I $\alpha$ overexpression is specific in SSA/Ps that predominantly arise in the right-side colon. In this regard, a few studies have reported that a proportion of colonic conventional adenomas also overexpress REG I $\alpha$ protein $[44,45]$. Therefore, we may have to investigate REG I $\alpha$ expression in not only SSA/Ps but also conventional adenomas while analyzing the relationship between REG I $\alpha$ expression and various clinicopathological features.

Finally, we investigated the relationship between $\beta$-catenin and REG I $\alpha$ protein in SSA/P lesions and clarified for the first time that $F n$ positivity was positively correlated with not only nuclear $\beta$-catenin expression but also the REG I $\alpha$ expression score. Moreover, it was noteworthy that SSA/P lesions with nuclear $\beta$-catenin expression had a significantly higher REG I $\alpha$ expression score. These finding suggest that nuclear translocation of $\beta$ catenin may be linked to enhancement of REG I $\alpha$ expression in SSA/P lesions. In this context, previous in vitro studies have shown that $\beta$-catenin signaling is responsible for 
REG I $\alpha$ expression [46], and that $\beta$-catenin mutation may be linked to aberrant REG I $\alpha$ overexpression in hepatocellular carcinoma [31]. Thus, since both $\beta$-catenin and REG I $\alpha$ are certainly involved in the progression of CRCs, the $\beta$-catenin/REG $\alpha$ axis may play a pivotal role in the growth of SSA/P lesions. One limitation of the present study was that signaling from $F n$ to the $\beta$-catenin/REG I $\alpha$ axis was not fully investigated. However, we preliminarily showed that nuclear $\beta$-catenin translocation by Wnt signaling activation may be closely associated with the enhancement of REG I $\alpha$ expression in colon cancer cells in vitro. Interestingly, recent studies have suggested that Wnt signaling may be a key pathway for Fn-associated cell growth in colon cancer $[11,47,48]$. Thus, since REG I $\alpha$ is able to function as a growth factor $[25,26]$, we would like to speculate that $F n$-associated $\beta$-catenin-nuclear translocation may play a role in the growth of SSA/P lesions, at least in part, via the growth-promoting effect of REG $\mathrm{I} \alpha$ protein.

In summary, we have demonstrated that nuclear $\beta$-catenin expression and REG I $\alpha$ overexpression are simultaneously evident in Fn-positive SSA/P lesions and that these are commonly correlated with the proliferative ability in such lesions. Although we were unable to investigate the pathway involved in signaling from $F n$ to the $\beta$-catenin/REG I $\alpha$ axis, the present findings at least suggest that $F n$ affects the proliferation of SSA/P lesions accompanied by promotion of $\beta$-catenin nuclear translocation and REG I $\alpha$ expression.

\section{Materials and Methods}

\subsection{Tissue Specimens and Clinicopathological Examination}

Thirty patients with SSA/P who underwent endoscopic submucosal dissection at Hyogo College of Medicine Hospital between 2016 and 2019 were enrolled. The SSA/P lesions examined were collected by endoscopic submucosal dissection $(n=16)$, endoscopic mucosal resection $(n=10)$ or polypectomy $(n=4)$. The tissue specimens obtained were fixed in $10 \%$ buffered formalin and embedded in paraffin, then cut into sections for pathological examination and immunohistochemistry. The characteristics of the patients and their lesions are listed in Table 3. The histological features of dysplastic change were assessed according to the previous descriptions $[29,36]$. This work was done with the approval of the Ethics Committee of Hyogo College of Medicine.

Table 3. Clinicopathological features of patients with SSA/Ps.

\begin{tabular}{lcc}
\hline Gender & & \\
\hline & Male & 16 \\
Age (years, mean \pm SE, range) & Female & 14 \\
Tumor location & & $64.5 \pm 2.2(31-83)$ \\
& Right side & 26 \\
Tumor size (mm, mean \pm SE, range) & Left side & 4 \\
Endoscopic morphology & & $21.1 \pm 1.5(6-40)$ \\
& Is/Isp & 2 \\
& IIa & 14 \\
\hline
\end{tabular}

LST-NG, laterally spreading tumor non-granular type.

\subsection{Immunohistochemistry}

Immunohistochemical staining for REG I $\alpha, \mathrm{Ki} 67$ and $\beta$-catenin was performed with an Envision Kit (Dako Agilent Technologies, Tokyo, Japan) as described previously [49], using anti-REG I $\alpha$ antibody (dilution; 1:2000), anti-Ki67 antibody (Dako Agilent Technologies, dilution; $1: 50$ ), and anti- $\beta$-catenin antibody (Cell Signaling Technology, Danvers, MA, USA; dilution; 1:500). In brief, the rehydrated sections were treated by microwave heating for 20 min in $1 \times$ Dako REAL Target Retrieval Solution (Dako Agilent Technologies) and then preincubated with $0.3 \% \mathrm{H}_{2} \mathrm{O}_{2}$ in methanol for $20 \mathrm{~min}$ at room temperature to quench endogenous peroxidase activity. The sections were then incubated with primary 
antibodies for $60 \mathrm{~min}$ at room temperature, washed in PBS, and incubated with horseradish peroxidase-conjugated secondary antibody for $30 \mathrm{~min}$. The slides were visualized using $3,3^{\prime}$-diaminobenzidine tetrahydrochloride with $0.05 \% \mathrm{H}_{2} \mathrm{O}_{2}$ for $3 \mathrm{~min}$ and then counterstained with Mayer's hematoxylin.

\subsection{Evaluation of Immunostaining}

For evaluation of immunohistochemical expression, crypts that were well oriented perpendicularly from the bottom to the surface of the colorectal epithelium were selected. The expression of REG I $\alpha$ was graded as previously described [50] with minor modification. Thus, it was scored according to the percentage of positive cells in a crypt as follows: score 0, a few cells; score 1, <10\%; score 2, 10-50\%; score 3, $>50 \%$. The Ki67 labeling index was expressed as the percentage of positive cells in a crypt. At least five different visual fields for each SSA/P lesion were observed, and the average REG I $\alpha$ score and Ki67 labeling index were calculated. $\beta$-catenin immunoreactivity was detected in the cytomembranes and nuclei of neoplastic cells in SSA/P lesions. When an SSA/P lesion showed $\beta$-catenin immunoreactivity not only in the cytomembranes but also the nucleus, it was classified as the nuclear type, whereas if $\beta$-catenin immunoreactivity was evident in the cytomembranes but not in the nucleus, the lesion was classified as the cytomembrane type.

\subsection{Fluorescence In Situ Hybridization (FISH)}

The sequence of the Fn-targeted probe, FUS664 (Cy3 labeled), was 5'-CTTGTAGTT CCGC(C/T)TACCTC-3'-(Chromosome Science Labo Inc., Sapporo, Japan). The 16 rRNAtargeted oligonucleotide probe was obtained from probe-Base (http:/ / www.microbialecology.net/probebase/) [34,51]. The tissue sections were deparaffinized and then hybridized with the Fn-targeted probe at $46^{\circ} \mathrm{C}$ for $2 \mathrm{~h}$ in accordance with the manufacturer's protocol. After hybridization, the slides were washed in buffer (40\% formamide, $0.9 \mathrm{M}$ $\mathrm{NaCl}, 0.01 \%$ SDS, $20 \mathrm{mM}$ Tris- $\mathrm{HCl}$ ) for $10 \mathrm{~min}$, then in phosphate-buffered saline, and counterstained with DAPI (Thermo Fisher Scientific, Tokyo, Japan).

SSA/P lesions were observed using a fluorescence microscope (DP72; Olympus, Tokyo, Japan; magnification $\times 200$ ) and fluorescent signals were recorded throughout each lesion (at least five different visual fields). The number of signal dots for $F n$ was counted in each field and the average was calculated. When the average Fn signal count was greater than 3.0/field, the lesion was considered to be positive.

\subsection{Stimulation for Caco2 Cells by Wnt Agonist SKL2001}

Human intestinal epithelial cell line Caco2 was obtained from ATCC (Manassas, VA, USA) and cultured in RPMI 1640 medium (Invitrogen, Carlsbad, CA, USA) with 10\% fetal bovine serum (Biowest, Nuaillé, France) in a humidified incubator at $37^{\circ} \mathrm{C}$ with an atmosphere of 5\% CO2. The cells were treated with Wnt agonist SKL2001 (40 $\mu \mathrm{M}$, Selleck, Houston, USA) for $24 \mathrm{~h}$.

Total RNA was isolated from the cells and reverse-transcribed using oligo-dT primer (Applied Biosystems, Branchburg, NJ). Thereafter, real-time RT-PCR was performed as previously reported [18]. In brief, the following sets of primers for human REG I $\alpha$ and glyceraldehydes-3-phosphate dehydrogenase $(G A P D H)$ were prepared: human REG I $\alpha 5^{\prime}$ CTAGAGGCAACTGGAAAATACATGTCT-3' (sense), 5'-GTTGGAGAGATGGTCCGGTTT3' (antisense), human GAPDH 5'-GAGTCAACGGATTTGGTCGT-3' (sense), 5' -TTGATTTT GGAGGGATCTCG-3' (antisense). The intensity of the fluorescent dye was determined, and the expression levels of REG I $\alpha$ mRNA were normalized to those of GAPDH mRNA.

The treated $\mathrm{Caco} 2$ cell were also subjected to immunostaining of $\beta$-catenin. Details are mentioned in the Figure 4 legend. Briefly, the cells were fixed with methanol, incubated with anti- $\beta$-catenin antibody (dilution 1:100; Cell Signaling), followed by TRITC-labeled secondary anti-rabbit antibodies (dilution 1:1000; DAKO), and counterstained using Antifade Mountant with DAPI (Life Technologies, Carlsbad, CA, USA). 


\subsection{Statistical Analysis}

All values were expressed as the mean \pm SE. Significance of differences between two animal groups was analyzed by Mann-Whitney $U$-test. Correlations between two parameters were assessed by linear regression analysis. Differences were considered to be significant at $p<0.05$.

Author Contributions: Conceptualization, H.N. and H.F.; experimentation, H.N., H.F., X.W., N.E., and T.N.; methodology, H.N., H.F., X.W., N.E., and T.N.; data acquisition and analysis, H.N., H.F., X.W., N.E., and T.N.; resources, H.N., H.F., X.W., N.E., T.N., T.T., T.O., and S.H.; writing—original draft preparation, N.E. and H.F.; writing-review and editing, N.E., H.F., T.T., T.O., S.H., and H.M.; supervision, T.T., T.O., S.H., and H.M. All authors have read and agreed to the published version of the manuscript.

Funding: This work was supported in part by Grants-in-aid for Scientific Research 17K09363 from the Ministry of Education, Culture, Sports, Science and Technology, Japan.

Institutional Review Board Statement: The study was conducted according to the guidelines of the Declaration of Helsinki and approved by the Ethics Committee of Hyogo College of Medicine (Protocol Identification Number: 3216).

Informed Consent Statement: Informed consent was obtained from all subjects involved in the study, and the opt out for this observational study was informed from Hyogo College of Medicine.

Data Availability Statement: The data presented in this study are available upon reasonable request from the corresponding author via hfukui@hyo-med.ac.jp.

Conflicts of Interest: The authors declare no conflict of interest.

\section{References}

1. Powell, S.M.; Zilz, N.; Beazer-Barclay, Y.; Bryan, T.M.; Hamilton, S.R.; Thibodeau, S.N.; Vogelstein, B.; Kinzler, K.W. APC mutations occur early during colorectal tumorigenesis. Nature 1992, 359, 235-237. [CrossRef] [PubMed]

2. O'Brien, M.J.; Yang, S.; Mack, C.; Xu, H.; Huang, C.S.; Mulcahy, E.; Amorosino, M.; Farraye, F.A. Comparison of microsatellite instability, CpG island methylation phenotype, BRAF and KRAS status in serrated polyps and traditional adenomas indicates separate pathways to distinct colorectal carcinoma end points. Am. J. Surg. Pathol. 2006, 30, 1491-1501. [CrossRef] [PubMed]

3. Leggett, B.; Whitehall, V. Role of the serrated pathway in colorectal cancer pathogenesis. Gastroenterology 2010, 138, 2088-2100. [CrossRef] [PubMed]

4. Okamoto, K.; Kitamura, S.; Kimura, T.; Nakagawa, T.; Sogabe, M.; Miyamoto, H.; Muguruma, N.; Takayama, T. Clinicopathological characteristics of serrated polyps as precursors to colorectal cancer: Current status and management. J. Gastroenterol. Hepatol. 2017, 32, 358-367. [CrossRef] [PubMed]

5. Shida, Y.; Ichikawa, K.; Fujimori, T.; Fujimori, Y.; Tomita, S.; Fujii, T.; Sano, Y.; Oda, Y.; Goto, H.; Ohta, A.; et al. Differentiation between sessile serrated adenoma/polyp and non-sessile serrated adenoma/polyp in large hyper plastic polyp: A Japanese collaborative study. Mol. Clin. Oncol. 2013, 1, 53-58. [CrossRef] [PubMed]

6. Song, M.; Chan, A.T.; Sun, J. Influence of the gut microbiome, diet, and environment on risk of colorectal cancer. Gastroenterology 2020, 158, 322-340. [CrossRef] [PubMed]

7. Castellarin, M.; Warren, R.L.; Freeman, J.D.; Dreolini, L.; Krzywinski, M.; Strauss, J.; Barnes, R.; Watson, P.; Allen-Vercoe, E.; Moore, R.A.; et al. Fusobacterium nucleatum infection is prevalent in human colorectal carcinoma. Genome Res. 2012, 22, $299-306$. [CrossRef]

8. Flanagan, L.; Schmid, J.; Ebert, M.; Soucek, P.; Kunicka, T.; Liska, V.; Bruha, J.; Neary, P.; Dezeeuw, N.; Tommasino, M.; et al. Fusobacterium nucleatum associates with stages of colorectal neoplasia development, colorectal cancer and disease outcome. Eur. J. Clin. Microbiol. Infect. Dis. 2014, 33, 1381-1390. [CrossRef]

9. Mima, K.; Nishihara, R.; Qian, Z.R.; Cao, Y.; Sukawa, Y.; Nowak, J.A.; Yang, J.; Dou, R.; Masugi, Y.; Song, M.; et al. Fusobacterium nucleatum in colorectal carcinoma tissue and patient prognosis. Gut 2016, 65, 1973-1980. [CrossRef]

10. Rubinstein, M.R.; Wang, X.; Liu, W.; Hao, Y.; Cai, G.; Han, Y.W. Fusobacterium nucleatum promotes colorectal carcinogenesis by modulating E-cadherin/ $\beta$-catenin signaling via its FadA adhesin. Cell Host Microbe 2013, 14, 195-206. [CrossRef]

11. Rubinstein, M.R.; Baik, J.E.; Lagana, S.M.; Han, R.P.; Raab, W.J.; Sahoo, D.; Dalerba, P.; Wang, T.C.; Han, Y.W. Fusobacterium nucleatum promotes colorectal cancer by inducing Wnt/ $\beta$-catenin modulator Annexin A1. EMBO Rep. 2019, 20, e47638. [CrossRef]

12. Terazono, K.; Yamamoto, H.; Takasawa, S.; Shiga, K.; Yonemura, Y.; Tochino, Y.; Okamoto, H. A novel gene activated in regenerating islets. J. Biol. Chem. 1988, 263, 2111-2114. [CrossRef]

13. Unno, M.; Yonekura, H.; Nakagawara, K.; Watanabe, T.; Miyashita, H.; Moriizumi, S.; Okamoto, H.; Itoh, T.; Teraoka, H. Structure, chromosomal localization, and expression of mouse reg genes, reg I and reg II. A novel type of reg gene, reg II, exists in the mouse genome. J. Biol. Chem. 1993, 268, 15974-15982. [CrossRef] 
14. Takasawa, S. Regenerating gene (REG) product and its potential clinical usage. Expert Opin. Ther. Targets 2016, 20, 541-550. [CrossRef]

15. Sekikawa, A.; Fukui, H.; Suzuki, K.; Karibe, T.; Fujii, S.; Ichikawa, K.; Tomita, S.; Imura, J.; Shiratori, K.; Chiba, T.; et al. Involvement of the IL-22/REG I $\alpha$ axis in ulcerative colitis. Lab. Invest. 2010, 90, 496-505. [CrossRef]

16. Van Beelen Granlund, A.; Østvik, A.E.; Brenna, Ø.; Torp, S.H.; Gustafsson, B.I.; Sandvik, A.K. REG gene expression in inflamed and healthy colon mucosa explored by in situ hybridization. Cell Tissue Res. 2013, 352, 639-646. [CrossRef]

17. Sun, C.; Fukui, H.; Hara, K.; Kitayama, Y.; Eda, H.; Yang, M.; Yamagishi, H.; Tomita, T.; Oshima, T.; Watari, J.; et al. Expression of Reg family genes in the gastrointestinal tract of mice treated with indomethacin. Am. J. Physiol. Gastrointest. Liver Physiol. 2015, 308, G736-G744. [CrossRef]

18. Xu, X.; Fukui, H.; Ran, Y.; Wang, X.; Inoue, Y.; Ebisudani, N.; Nishimura, H.; Tomita, T.; Oshima, T.; Watari, J.; et al. The link between type III Reg and STAT3-associated cytokines in inflamed colonic tissues. Mediat. Inflamm. 2019, 2019, 7859460. [CrossRef]

19. Yamagishi, H.; Fukui, H.; Sekikawa, A.; Kono, T.; Fujii, S.; Ichikawa, K.; Tomita, S.; Imura, J.; Hiraishi, H.; Chiba, T.; et al. Expression profile of REG family proteins REG I $\alpha$ and REG IV in advanced gastric cancer: Comparison with mucin phenotype and prognostic markers. Mod. Pathol. 2009, 22, 906-913. [CrossRef]

20. Zheng, H.C.; Sugawara, A.; Okamoto, H.; Takasawa, S.; Takahashi, H.; Masuda, S.; Takano, Y. Expression profile of the REG gene family in colorectal carcinoma. J. Histochem. Cytochem. 2011, 59, 106-115. [CrossRef]

21. Sekikawa, A.; Fukui, H.; Zhang, X.; Maruo, T.; Tsumura, T.; Okabe, Y.; Wakasa, T.; Osaki, Y.; Chiba, T.; Tomita, T.; et al. REG I $\alpha$ is a biomarker for predicting response to chemotherapy with S-1 plus cisplatin in patients with unresectable stage IV gastric cancer. Br. J. Cancer 2013, 108, 395-401. [CrossRef]

22. Bishnupuri, K.S.; Luo, Q.; Korzenik, J.R.; Henderson, J.O.; Houchen, C.W.; Anant, S.; Dieckgraefe, B.K. Dysregulation of Reg gene expression occurs early in gastrointestinal tumorigenesis and regulates anti-apoptotic genes. Cancer Biol. Ther. 2006, 5, 1714-1720. [CrossRef]

23. Nanakin, A.; Fukui, H.; Fujii, S.; Sekikawa, A.; Kanda, N.; Hisatsune, H.; Seno, H.; Konda, Y.; Fujimori, T.; Chiba, T. Expression of the REG IV gene in ulcerative colitis. Lab. Invest. 2007, 87, 304-314. [CrossRef]

24. Zhang, M.Y.; Wang, J.; Guo, J. Role of regenerating islet-derived protein 3A in gastrointestinal cancer. Front. Oncol. 2019,9 , 1449. [CrossRef]

25. Fukui, H.; Kinoshita, Y.; Maekawa, T.; Okada, A.; Waki, S.; Hassan, S.; Okamoto, H.; Chiba, T. Regenerating gene protein may mediate gastric mucosal proliferation induced by hypergastrinemia in rats. Gastroenterology 1998, 115, 1483-1493. [CrossRef]

26. Sekikawa, A.; Fukui, H.; Fujii, S.; Takeda, J.; Nanakin, A.; Hisatsune, H.; Seno, H.; Takasawa, S.; Okamoto, H.; Fujimori, T.; et al. REG I $\alpha$ protein may function as a trophic and/or anti-apoptotic factor in the development of gastric cancer. Gastroenterology 2005, 128, 642-653. [CrossRef] [PubMed]

27. Sekikawa, A.; Fukui, H.; Fujii, S.; Nanakin, A.; Kanda, N.; Uenoyama, Y.; Sawabu, T.; Hisatsune, H.; Kusaka, T.; Ueno, S.; et al. Possible role of REG I $\alpha$ protein in ulcerative colitis and colitic cancer. Gut 2005, 54, 1437-1444. [CrossRef] [PubMed]

28. Sekikawa, A.; Fukui, H.; Fujii, S.; Ichikawa, K.; Tomita, S.; Imura, J.; Chiba, T.; Fujimori, T. REG I $\alpha$ protein mediates an anti-apoptotic effect of STAT3 signaling in gastric cancer cells. Carcinogenesis 2008, 29, 76-83. [CrossRef] [PubMed]

29. Murakami, T.; Mitomi, H.; Saito, T.; Takahashi, M.; Sakamoto, N.; Fukui, N.; Yao, T.; Watanabe, S. Distinct WNT/ $\beta$-catenin signaling activation in the serrated neoplasia pathway and the adenoma-carcinoma sequence of the colorectum. Mod. Pathol. 2015, 28, 146-158. [CrossRef]

30. Nourbakhsh, M.; Mansoor, A.; Koro, K.; Zhang, Q.; Minoo, P. Expression profiling reveals involvement of Wnt pathway in the malignant progression of sessile serrated adenomas. Am. J. Pathol. 2019, 189, 1732-1743. [CrossRef]

31. Cavard, C.; Terris, B.; Grimber, G.; Christa, L.; Audard, V.; Radenen-Bussiere, B.; Simon, M.T.; Renard, C.A.; Buendia, M.A.; Perret, C. Overexpression of regenerating islet-derived 1 alpha and 3 alpha genes in human primary liver tumors with beta-catenin mutations. Oncogene 2006, 25, 599-608. [CrossRef]

32. Hakata, Y.; Fukui, H.; Sekikawa, A.; Yamagishi, H.; Ichikawa, K.; Tomita, S.; Imura, J.; Kawamata, H.; Imai, Y.; Fujimori, T. Expression of $\beta$-catenin and REG I $\alpha$ in relation to cell proliferative ability in salivary gland tumors. Exp. Ther. Med. 2010, 1, 437-443. [CrossRef]

33. Sayed, I.M.; Sahan, A.Z.; Venkova, T.; Chakraborty, A.; Mukhopadhyay, D.; Bimczok, D.; Beswick, E.J.; Reyes, V.E.; Pinchuk, I.; Sahoo, D.; et al. Helicobacter pylori infection downregulates the DNA glycosylase NEIL2, resulting in increased genome damage and inflammation in gastric epithelial cells. J. Biol. Chem. 2020, 295, 11082-11098. [CrossRef]

34. Yu, J.; Chen, Y.; Fu, X.; Zhou, X.; Peng, Y.; Shi, L.; Chen, T.; Wu, Y. Invasive Fusobacterium nucleatum may play a role in the carcinogenesis of proximal colon cancer through the serrated neoplasia pathway. Int. J. Cancer 2016, 139, 1318-1326. [CrossRef]

35. Sayed, I.M.; Chakraborty, A.; Abd El-Hafeez, A.A.; Sharma, A.; Sahan, A.Z.; Huang, W.J.M.; Sahoo, D.; Ghosh, P.; Hazra, T.K.; Das, S. The DNA glycosylase NEIL2 suppresses Fusobacterium-infection-induced inflammation and DNA damage in colonic epithelial cells. Cells 2020, 9, 1980. [CrossRef]

36. Fujita, K.; Yamamoto, H.; Matsumoto, T.; Hirahashi, M.; Gushima, M.; Kishimoto, J.; Nishiyama, K.; Taguchi, T.; Yao, T.; Oda, Y. Sessile serrated adenoma with early neoplastic progression: A clinicopathologic and molecular study. Am. J. Surg. Pathol. 2011, 35, 295-304. [CrossRef]

37. Chen, Y.; Peng, Y.; Yu, J.; Chen, T.; Wu, Y.; Shi, L.; Li, Q.; Wu, J.; Fu, X. Invasive Fusobacterium nucleatum activates beta-catenin signaling in colorectal cancer via a TLR4/P-PAK1 cascade. Oncotarget 2017, 8, 31802-31814. [CrossRef] 
38. Clevers, H.; Nusse, R. Wnt/ $\beta$-catenin signaling and disease. Cell 2012, 149, 1192-1205. [CrossRef]

39. Vishnoi, K.; Viswakarma, N.; Rana, A.; Rana, B. Transcription factors in cancer development and therapy. Cancers 2020, $12,2296$. [CrossRef]

40. Yachida, S.; Mudali, S.; Martin, S.A.; Montgomery, E.A.; Iacobuzio-Donahue, C.A. Beta-catenin nuclear labeling is a common feature of sessile serrated adenomas and correlates with early neoplastic progression after BRAF activation. Am. J. Surg. Pathol. 2009, 33, 1823-1832. [CrossRef]

41. Murakami, T.; Akazawa, Y.; Yatagai, N.; Hiromoto, T.; Sasahara, N.; Saito, T.; Sakamoto, N.; Nagahara, A.; Yao, T. Molecular characterization of sessile serrated adenoma/polyps with dysplasia/carcinoma based on immunohistochemistry, next-generation sequencing, and microsatellite instability testing: A case series study. Diagn. Pathol. 2018, 13, 88. [CrossRef]

42. Murakami, T.; Sakamoto, N.; Nagahara, A. Clinicopathological features, diagnosis, and treatment of sessile serrated adenoma/polyp with dysplasia/carcinoma. J. Gastroenterol. Hepatol. 2019, 34, 1685-1695. [CrossRef]

43. Chen, Z.; Downing, S.; Tzanakakis, E.S. Four decades after the discovery of regenerating islet-derived (Reg) proteins: Current understanding and challenges. Front. Cell Dev. Biol. 2019, 7, 235. [CrossRef]

44. Zenilman, M.E.; Kim, S.; Levine, B.A.; Lee, C.; Steinberg, J.J. Ectopic expression of reg protein: A marker of colorectal mucosa at risk for neoplasia. J. Gastrointest. Surg. 1997, 1, 194-202. [CrossRef]

45. Rechreche, H.; Montalto, G.; Mallo, G.V.; Vasseur, S.; Marasa, L.; Soubeyran, P.; Dagorn, J.C.; Iovanna, J.L. pap, reg I alpha and reg I beta mRNAs are concomitantly up-regulated during human colorectal carcinogenesis. Int. J. Cancer 1999, 81, 688-694. [CrossRef]

46. Jing, D.; Kehoe, D.E.; Tzanakakis, E.S. Expression of Reg family proteins in embryonic stem cells and its modulation by Wnt/beta-catenin signaling. Stem Cells Dev. 2010, 19, 1307-1319. [CrossRef]

47. Lin, R.; Han, C.; Ding, Z.; Shi, H.; He, R.; Liu, J.; Qian, W.; Zhang, Q.; Fu, X.; Deng, X.; et al. Knock down of BMSC-derived Wnt3a or its antagonist analogs attenuate colorectal carcinogenesis induced by chronic Fusobacterium nucleatum infection. Cancer Lett. 2020, 495, 165-179. [CrossRef] [PubMed]

48. Li, X.; Huang, J.; Yu, T.; Fang, X.; Lou, L.; Xin, S.; Ji, L.; Jiang, F.; Lou, Y. Fusobacterium nucleatum promotes the progression of colorectal cancer through Cdk5-activated Wnt/ $\beta$-catenin signaling. Front. Microbiol. 2021, 11, 545251. [CrossRef] [PubMed]

49. Hara, K.; Fukui, H.; Sun, C.; Kitayama, Y.; Eda, H.; Yamasaki, T.; Kondo, T.; Tomita, T.; Oshima, T.; Watari, J.; et al. Effect of REG $\mathrm{I} \alpha$ protein on angiogenesis in gastric cancer tissues. Oncol. Rep. 2015, 33, 2183-2189. [CrossRef] [PubMed]

50. Okamoto, K.; Fujimori, T.; Yamaguchi, T.; Ichikawa, K.; Tomita, S.; Sugai, T.; Imura, J.; Ohkura, Y.; Yao, T.; Fujii, S.; et al. Overexpression of regenerating gene I $\alpha$ appears to reflect aberration of crypt cell compartmentalization in sessile serrated adenoma/polyps of the colon. Diagn. Pathol. 2013, 8, 187. [CrossRef]

51. Loy, A.; Arnold, R.; Tischler, P.; Rattei, T.; Wagner, M.; Horn, M. ProbeCheck-a central resource for evaluating oligonucleotide probe coverage and specificity. Environ. Microbiol. 2008, 10, 2894-2898. [CrossRef] 